\title{
Increased Secretory Demand Rather than a Defect in the Proinsulin Conversion Mechanism Causes Hyperproinsulinemia in a Glucose-Infusion Rat Model of Non-Insulin-dependent Diabetes Mellitus
}

\author{
Cristina Alarcón, Jack L. Leahy, ${ }^{\S}$ George T. Schuppin, and Christopher J. Rhodes \\ E. P. Joslin Research Laboratory, Joslin Diabetes Center, Brigham and Women's Hospital and Harvard Medical School, Boston, \\ Massachusetts 02215, and ${ }^{\S}$ Department of Endocrinology, Diabetes, Metabolism and Molecular Medicine, New England Medical Center, \\ Tuft's University, Boston, Massachusetts 02111
}

\begin{abstract}
Hyperproinsulinemia in non-insulin-dependent diabetes mellitus (NIDDM) is due to an increased release of proinsulin from pancreatic $\beta$ cells. This could reside in increased secretory demand placed on the $\beta$ cell by hyperglycemia or in the proinsulin conversion mechanism. In this study, biosynthesis of the proinsulin conversion enzymes (PC2, PC3, and carboxypeptidase-H $[\mathrm{CP}-\mathrm{H}]$ ) and proinsulin, were examined in islets isolated from 48 -h infused rats with $50 \%$ (wt/vol) glucose (hyperglycemic, hyperinsulinemic, and increased pancreatic proinsulin to insulin ratio), $20 \%$ (wt/vol) glucose (normoglycemic but hyperinsulinemic), and $0.45 \%$ (wt/vol) saline (controls). A decrease in the islet content of PC2, PC3, and CP-H from hyperglycemic rats was observed. This reduction did not correlate with any deficiency in mRNA levels or biosynthesis of PC2, PC3, CP$\mathrm{H}$, or proinsulin. Furthermore, proinsulin conversion rate was comparable in islets from hyperglycemic and control rats. However, in islets from hyperglycemic rats an abnormal increased proportion of proinsulin was secreted, that was accompanied by an augmented release of $\mathrm{PC2}, \mathrm{PC} 3$ and CP-H. Stimulation of the $\beta$ cell's secretory pathway by hyperglycemia, resulted in proinsulin being prematurely secreted from islets before its conversion could be completed. Thus, hyperproinsulinemia induced by chronic hyperglycemia likely results from increased $\beta$ cell secretory demand, rather than a defect in the proinsulin processing enzymes per se. (J. Clin. Invest. 1995. 95:1032-1039.) Key words: PC2 - PC3 • carboxypeptidase-H • proinsulin • pancreatic islets $\cdot$ diabetes
\end{abstract}

\section{Introduction}

Insulin is initially synthesized in the pancreatic $\beta$ cell as a larger precursor molecule proinsulin which then undergoes limited proteolysis in the secretory granule to insulin and C-peptide (1-3). The proteolytic process involves endoproteolytic cleavages at $\mathrm{Arg}^{31}, \mathrm{Arg}^{32}$, and $\mathrm{Lys}^{64}, \mathrm{Arg}^{65}$ by two distinct $\mathrm{Ca}^{2+}$.

Address correspondence to Christopher J. Rhodes, Ph.D., E. P. Joslin Research Laboratory, Joslin Diabetes Center, Room 640D, One Joslin Place, Boston, MA 02215. Phone: 617-732-2629; FAX: 617-723-2527.

Received for publication 27 June 1994 and in revised form 15 November 1994.

J. Clin. Invest.

(c) The American Society for Clinical Investigation, Inc. 0021-9738/95/03/1032/08 \$2.00

Volume 95, March 1995, 1032-1039 dependent endopeptidases, named PC2 and PC3 (3-6). The newly exposed $\mathrm{COOH}$-terminal basic amino acids are subsequently removed by the exopeptidase carboxypeptidase-H (CP$\mathrm{H})^{1}$ (7). PC2 and PC3 (also known as PC1) (8) are members of the novel family of proprotein convertases (PCs) related to bacterial subtilisin and the yeast processing endopeptidase, Kex$2(9,10)$. PC3 is specific for the $\operatorname{Arg}^{31}, \operatorname{Arg}^{32}$ site (11-14), and PC2 has a strong preference for the Lys ${ }^{64}, \operatorname{Arg}^{65}$ site (11, 15). The bulk of the evidence for human proinsulin processing supports a sequential mechanism whereby PC 3 cleaves intact proinsulin to des 31,32 proinsulin followed by the $P C 2$ cleavage (3). As such, we have proposed that PC3 is the controlling endopeptidase for human proinsulin processing (3).

Proinsulin conversion to insulin is normally very efficient, with $>90 \%$ of the secreted insulin-like molecules being native insulin and C-peptide $(16,17)$. However, in persons with noninsulin-dependent diabetes mellitus (NIDDM) the levels of proinsulin (and the conversion intermediates) relative to insulin in the blood are raised (for reviews see references 18-21). The metabolic clearance rate of proinsulin is unchanged in NIDDM $(19,22)$, making the cause a relative hypersecretion of the proinsulin-like peptides which agrees with our finding of higher levels of proinsulin relative to insulin in pancreas extracts from two hyperglycemic rat models $(23,24)$. In animal models an increased pancreatic proinsulin to insulin ratio tended to correlate with hyperglycemia, since it was found where plasma insulin levels were normal (23). Hypersecretion of incompletely processed forms of insulin worsens the insulin deficiency in NIDDM, since proinsulin and the conversion intermediates are biologically poorly active compared to insulin $(22,25)$. Two hypotheses to account for the hypersecretion of proinsulin have been suggested $(3,19)$. First, a heightened demand on insulin secretion from the hyperglycemia depletes the $\beta$ cell of mature insulin granules, resulting in an enriched population of less mature (proinsulin-rich) granules for secretion. Alternatively, a defect in the enzymatic proinsulin processing mechanism has been proposed.

The present study investigated these two hypotheses using a rat model (48-h glucose infusion) (26) which is known to have a raised proportion of proinsulin relative to insulin in their $\beta$ cells (24). The gene expression, biosynthesis, processing, and secretion of proinsulin, $\mathrm{PC} 2, \mathrm{PC} 3$, and $\mathrm{CP}-\mathrm{H}$ were measured in pancreatic islets isolated from three groups of rats: $(a)$ rats infused with $50 \%(\mathrm{wt} / \mathrm{vol})$ glucose that are hyperglycemic and are known to have a raised pancreatic ratio of proinsulin to

1. Abbreviations used in this paper: $\mathrm{CP}-\mathrm{H}$, carboxypeptidase- $\mathrm{H}$; NIDDM, non-insulin-dependent diabetes mellitus; PC, proprotein convertase. 
insulin $(24,26,27) ;(b)$ rats infused with $20 \%$ (wt/vol) glucose that develop compensatory hyperinsulinemia while maintaining a normal basal level of blood glucose and a normal pancreatic proinsulin to insulin ratio $(26,27) ; 3)$ control rats infused with $0.45 \%$ saline (wt/vol).

\section{Methods}

Materials. L- $\left[{ }^{35} \mathrm{~S}\right]$ methionine $(1.2 \mathrm{mCi} / \mathrm{mmol})$ and $\alpha-\left[{ }^{32} \mathrm{P}\right] \mathrm{dCTP}$ $(3,000 \mathrm{Ci} / \mathrm{mmol})$ were from DuPont-New England Nuclear (Cambridge, MA). Restriction endonucleases were from Stratagene (La Jolla, CA) or NE BioLabs (Cambridge, MA). All other analytical-grade biochemicals were from Sigma Chemical Co. (St. Louis, MO) or Fisher Scientific (Springfield, NJ).

Glucose-infused rat model. 200-g male Sprague-Dawley rats were infused for $48 \mathrm{~h}$ with either $0.45 \% \mathrm{NaCl}, 20 \%$ glucose, or $50 \%$ glucose at a flow rate of $2 \mathrm{ml} / \mathrm{h}$, as previously described $(24,26,27)$. Blood samples obtained at the end of the infusion by tail snipping, were assessed for plasma glucose levels using a Beckman glucose analyzer II (Beckman Instruments, San Ramon, CA).

Islet isolation. Pancreatic islets were isolated from glucose/salineinfused rats by pancreas digestion with collagenase and islet isolation by Histopaque density gradient centrifugation, as previously described (28).

Pulse-chase $\left[{ }^{35} \mathrm{~S}\right]$ methionine-radiolabeling experiments. Batches of 100 islets were incubated for $40 \mathrm{~min}$ at $37^{\circ} \mathrm{C}$ under $\mathrm{O}_{2} / \mathrm{CO}_{2}(95 / 5 \%)$ in $1.5-\mathrm{ml}$ microcentrifuge tubes in $0.1 \mathrm{ml}$ of modified Krebs-Ringer bicarbonate buffer $\left(115 \mathrm{mM} \mathrm{NaCl}, 5 \mathrm{mM} \mathrm{KCl}, 10 \mathrm{mM} \mathrm{NaHCO}_{3}, 2.5\right.$ $\mathrm{mM} \mathrm{MgCl} 2,2.5 \mathrm{mM} \mathrm{CaCl}_{2}$ ), $20 \mathrm{mM}$ Hepes, $0.1 \%$ bovine serum albu-

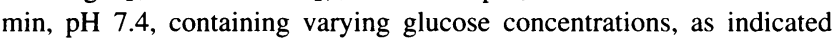
for each experiment. Islets were recovered by centrifugation ( $800 \mathrm{~g}$ for $15 \mathrm{~s}$ ), and pulse-radiolabeled at $37^{\circ} \mathrm{C}$ in $0.1 \mathrm{ml}$ of the fresh incubation buffer containing $0.25 \mathrm{mCi}$ of $\left[{ }^{35} \mathrm{~S}\right]$ methionine. After 20-30 min pulse medium was removed by centrifugation, islets washed with $1 \mathrm{ml}$ of incubation buffer containing $2 \mathrm{mM} \mathrm{L}$-methionine and chased for varying times in $0.1 \mathrm{ml}$ of $2 \mathrm{mM} \mathrm{L}$-methionine-containing buffer, at the glucose concentration indicated for each experiment. The medium was removed by centrifugation ( $800 \mathrm{~g}$ for $15 \mathrm{~s}$ ) and the islets were resuspended in $250 \mu \mathrm{l}$ of lysis buffer ( $50 \mathrm{mM}$ Hepes, $\mathrm{pH} 8.0,1 \%$ Triton X-100, 10 $\mu \mathrm{M}$ phenylmethylsulfonyl fluoride, $10 \mu \mathrm{M}$ trans-epoxysuccinyl-L-leucyl-amido-(4-guanidino)butane, $10 \mu \mathrm{M}$ pepstatin A, $10 \mu \mathrm{M} \mathrm{N}^{\alpha}$ - $p$-tosyl-L-lysine chloromethyl ketone, $0.1 \mathrm{mM}$ leupeptin, $0.1 \% \mathrm{NaN}_{3}$ ) and sonicated ( 25 watts for $20 \mathrm{~s}$ ). Islet lysates were centrifuged for $2 \mathrm{~min}$ at $10,000 \mathrm{~g}$ and supernatants collected. The presence of $\left[{ }^{35} \mathrm{~S}\right]$ methionineradiolabeled proteins in islet lysates and incubation media was analyzed by trichloroacetic acid (TCA) precipitation in a 5- $\mu$ l aliquot, as previously described (29).

Proinsulin, PC2, PC3, and CP-H immunoprecipitation and analysis. Islet lysates and incubation media were incubated for $2 \mathrm{~h}$ at room temperature with $25 \mu \mathrm{l}$ of Cowan's strain Staphyloccocus aureus cells (Sigma Chemical Co.). The supernatant obtained after centrifugation ( $10,000 \mathrm{~g}$ for $2 \mathrm{~min}$ ) was subjected to serial immunoprecipitation for PC2, PC3, proinsulin and CP-H. PC2 and PC3 were specifically immunoprecipitated as previously described (29). (Pro) insulin was immunoprecipitated, as described (29), using $10 \mu \mathrm{l}$ of bovine insulin antiserum (Sigma Chemical Co.) for islet lysates, and $2 \mu \mathrm{l}$ for the incubation media. CP-H was specifically immunoprecipitated with $4 \mu \mathrm{l}$ of $\mathrm{CP}-\mathrm{H}$ antisera (30) (generous gift of Dr. L. Fricker, New York). Immunoprecipitated proteins were analyzed by polyacrylamide gel electrophoresis and fluorography, as previously described (29). Fluorographs were subjected to densitometric scanner analysis (Computing Densitometer; Molecular Dynamics, Sunnyvale, CA).

Immunoblot analysis. Batches of 500 islets from glucose/salineinfused rats were resuspended in $20 \mu \mathrm{l}$ of Laemmli sample buffer (31), $1 \mu \mathrm{l}$ of $1 \mathrm{M}$ DTT added, then heated at $96^{\circ} \mathrm{C}$ for $5 \mathrm{~min}$ and centrifuged $(10,000 \mathrm{~g}, 2 \mathrm{~min})$. Aliquots $(5 \mu \mathrm{l})$ of supernatant were subjected to SDS-PAGE (29). Separated proteins were semi-dry blot transferred from the gel onto a nitrocellulose membrane and then subjected to immunoblot analysis for PC2, PC3, and CP-H, as described (29).

Northern blot analysis. Total RNA was extracted from glucose/ saline-infused rat isolated islets using RNAzol ${ }^{\text {ॠD }}$ (Biotec Laboratories, Inc., Houston, TX). Extracted total islet RNA ( $5 \mu \mathrm{g})$ were fractionated by $1 \%$ agarose/formaldehyde gel electrophoresis. RNA was capillary transferred onto a Biotrans ${ }^{\oplus \infty}$ nylon membrane (ICN, Irvine, CA) for $24 \mathrm{~h}$ and fixed to the membrane by long wave UV irradiation. The blot was prehybridized for $3 \mathrm{~h}$ at $42^{\circ} \mathrm{C}$ in $50 \mathrm{mM}$ PIPES, $100 \mathrm{mM} \mathrm{NaCl}$, $50 \mathrm{mM}$ sodium phosphate buffer ( $\mathrm{pH} 7.0$ ), containing $1 \mathrm{mM}$ EDTA, $5 \%$ SDS and $60 \mu \mathrm{g} / \mathrm{ml}$ denature salmon sperm DNA. Hybridization was carried out for $24-48 \mathrm{~h}$ at $42^{\circ} \mathrm{C}$ in fresh medium containing $\left[{ }^{32} \mathrm{P}\right]-$ CTP-radiolabeled probes for PC2, PC3, CP-H, or insulin. The membrane was washed with $2 \mathrm{X} \mathrm{SSC,} 0.1 \%$ SDS once at room temperature for 15 min and three times at $65^{\circ} \mathrm{C}$ for $10 \mathrm{~min}$, and autoradiographed. cDNA probes were random primer radiolabeled, according to Prime-It ${ }^{\text {TII }}$ II Stratagene protocol. The PC 2 cDNA (obtained from Dr. Al Rehemtulla, The Genetics Institute, Cambridge, MA), comprising residues 1372337, was obtained by Hind III digestion of PC2 cDNA clone (5), and PC3 cDNA (also from Dr. Al Rehemtulla), comprising residues 1902701, was from Pstl digested PC3 cDNA clone (6). The CP-H probe was obtained by EcoRI digestion of CP-H cDNA clone (32) (a gift from Dr. Lloyd Fricker, Albert Einstein College of Medicine, Bronx, NY). Proinsulin probe ( 424 base pair length) was obtained by HindIII and EcoRI digestion of rat insulin-II cDNA clone (33) (from Dr. Lydia Villa-Komaroff, Children's Hospital, Boston, MA). Digested cDNA was purified in $1 \%$ agarose gel, followed by Glassmilk ${ }^{\circledR}$ (Geneclean II ${ }^{\circledR}$; BIO 101 Inc., La Jolla, CA) precipitation of the DNA from the appropriate agarose band.

\section{Results}

General characteristics of glucose-infused rats. The rats infused with $50 \%$ glucose were markedly hyperglycemic at the end of the infusion $(16.4 \pm 1.6[n=8] \mathrm{mM}$ glucose verses $7.6 \pm 0.2[n$ $=8] \mathrm{mM}$ glucose in saline infused controls $)(P<0.002$ Student's $t$ test), as opposed to the $20 \%$ glucose group in which the basal plasma glucose level was equal to the saline controls $(8.1 \pm 0.2[n=8] \mathrm{mM}$; not significant verses saline-infused controls). Certain characteristics of this glucose-infusion rat model have been previously reported $(24,26,27)$, that are germane to this study. In the $50 \%$ glucose-infused rats there is marked hyperinsulinemia, a reduced pancreatic insulin content to $30 \%$ of normal, and a raised proinsulin to insulin ratio in pancreatic extracts. In the $20 \%$ glucose-infused rats there is less severe hyperinsulinemia, a normal pancreatic insulin content, and a normal pancreatic proinsulin to insulin ratio when compared with saline-infused controls. Thus, comparison of the 20 and $50 \%$ glucose-infused rat groups allowed us to investigate effects on (pro) insulin synthesis, processing, and secretion under two quite different circumstances: $(a)$ a severe model where hyperinsulinemia cannot compensate for overt chronic hyperglycemia (50\% glucose-infused rat); and $(b)$ a milder model where a heightened insulin secretory rate maintains normoglycemia (20\% glucose-infused rat).

Islet content of proinsulin, $P C 2, P C 3$, and $C P-H$. The islet content of PC2, PC3, and $\mathrm{CP}-\mathrm{H}$ by immunoblotting was markedly lower in the $50 \%$ glucose-infused rats compared to the saline-infused rats (Fig. 1). In contrast, the levels of these proteins were not different in the $20 \%$ glucose-infused islets and the control (saline-infused) islets. This observation generally parallels that previously observed for insulin content in the same glucose infused model $(26,27)$. In regard to the $50 \%$ glucose islets, the reduction in PC3 exceeded that of PC2 or CP-H. This 


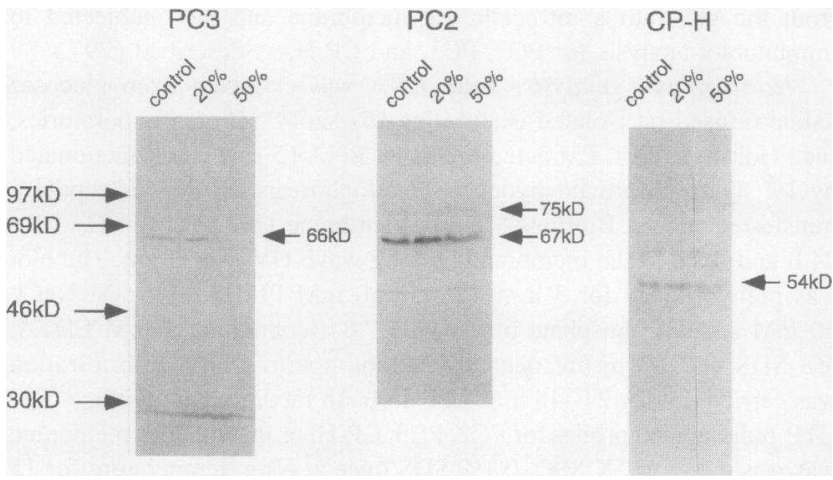

Figure 1. Immunoblot analysis of the proinsulin-processing enzymes. Isolated islets from rats infused for $48 \mathrm{~h}$ with $0.45 \% \mathrm{NaCl}$ (control), $20 \%$-glucose $(20 \%)$, and $50 \%$-glucose $(50 \%)$ were immunoblot analyzed, as previously described (see Methods), using specific antibodies for PC3, PC2, and CP-H. An example blot is shown as representative of 3-4 separate experiments. The migration of molecular size standards is indicated.

finding likely reflects the localization of these proteins, since PC3 is predominately expressed in $\beta$ cells (26-fold higher PC3 protein expression in islet $\beta$ cells verses non $-\beta$ cells) (34), as opposed to PC2 and CP-H that are also abundant in the non$\beta$ cells of the islet $(34,35)$. As such, a reduction of the $\beta$ cell content of these proteins would appear to cause a greater fall in the islet level of PC3. Consistent with this idea, pancreatic glucagon content is normal in the $50 \%$ glucose-infused rats in contrast to the marked depletion of insulin (27).

Islet biosynthesis of proinsulin, $P C 2, P C 3$, and $C P-H$. To determine whether a defect in the production of PC2, PC3, CP$\mathrm{H}$, and proinsulin caused lowered islet content in $50 \%$ glucoseinfused rat islets, the gene expression of these proteins was examined. Northern blot analysis showed no reduction of the PC2, PC3, CP-H, and preproinsulin-II total mRNA content in isolated islets from hyperglycemic rats versus control and $20 \%$ glucose infused rats (Fig. 2). On the contrary, in islets from both the $20 \%$ and $50 \%$ glucose-infusions PC3 and preproinsulin mRNAs were increased, whereas no measurable change in mRNA levels of PC2 or CP-H with increasing hyperglycemia was observed (Fig. 2).

The biosynthesis of proinsulin, PC3, PC2, and $\mathrm{CP}-\mathrm{H}$, as

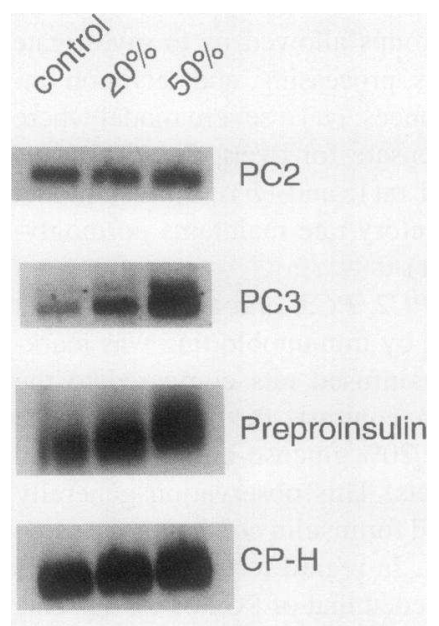

Figure 2. Northern blot analysis of the proinsulin-processing enzymes. Total RNA ( $5 \mu \mathrm{g} /$ lane) from isolated islets of rats infused for $48 \mathrm{~h}$ with $0.45 \% \mathrm{NaCl}$ (control), 20\%-glucose (20\%), and $50 \%$-glucose $(50 \%)$ was fractionated and transferred to a nylon membrane. The blot was prehybridized for $3 \mathrm{~h}$ at $42^{\circ} \mathrm{C}$ and hybridized for $24-48 \mathrm{~h}$ at $42^{\circ} \mathrm{C}$ successively with $\left[{ }^{32} \mathrm{P}\right]$-labeled PC2, PC3, CP-H, and insulin cDNA probes.

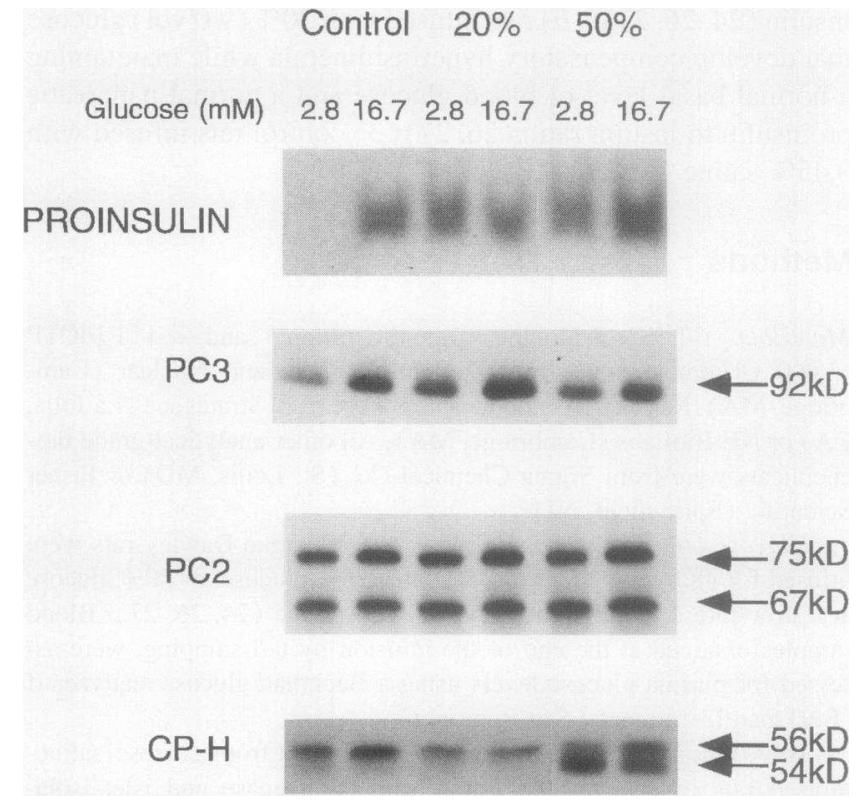

Figure 3. Glucose regulation of the biosynthesis of proinsulin and proinsulin-processing enzymes. Isolated islets from rats infused for $\mathbf{4 8}$ hours with $0.45 \% \mathrm{NaCl}$ (control), 20\%-glucose (20\%), and 50\%-glucose ( $50 \%$ ) were incubated for $70 \mathrm{~min}$ in modified Krebs-Ringer bicarbonate buffer containing 2.8 or $16.7 \mathrm{mM}$ glucose, the final $30 \mathrm{~min}$ were in the additional presence of $\left[{ }^{35}\right.$ S $]$ methionine. Proinsulin, PC2, PC3, and CP$\mathrm{H}$ were sequentially immunoprecipitated from islet lysates and analyzed by polyacrylamide gel electrophoresis followed by fluorography. An example fluorogram is shown as representative of 2-4 separate experiments.

determined by $30-\min \left[{ }^{35} \mathrm{~S}\right]$ methionine-radiolabeling of isolated islets, was not reduced in 50\%-glucose infused hyperglycemic rats versus control and $20 \%$ glucose-infused rats (Fig. 3). $\left[{ }^{35} \mathrm{~S}\right]$ methionine incorporation into total (TCA-precipitable) islet proteins was equivalent in the three groups of islets. In islets from saline-infused control rats the biosynthesis of proinsulin and $\mathrm{PC} 3$, but not that of $\mathrm{PC} 2$ or $\mathrm{CP}-\mathrm{H}$, was increased by short term exposure to stimulatory $16.7 \mathrm{mM}$ glucose versus that at basal $2.8 \mathrm{mM}$ glucose concentrations (Fig. 3), in agreement with previous observations $(28,29)$. However, in islets from both 20 and $50 \%$ glucose-infused rats the basal rate of proinsulin and PC3 biosynthesis at $2.8 \mathrm{mM}$ glucose was increased to that of $16.7 \mathrm{mM}$ glucose control stimulatory levels (Fig. 3). Nevertheless, a degree of glucose regulation was still present in $50 \%$ glucose-infused islets, since an incubation at a stimulatory $16.7 \mathrm{mM}$ glucose further stimulated proinsulin biosynthesis above the already increased basal rate at $2.8 \mathrm{mM}$ glucose. There was no effect of the 20 or $50 \%$ glucose-infusions on islet PC2 and CP-H biosynthesis other than a slight increase in the processing of the precursor $56-\mathrm{kD}$ form of $\mathrm{CP}-\mathrm{H}$ to the mature $54-\mathrm{kD}$ form in the $50 \%$ glucose-infused islets. In summary, the biosynthesis of proinsulin and the conversion enzymes was not negatively impaired in the hyperglycemic glucose-infused islets that would account for a reduction in the islet content of these proteins (Fig. 1).

Islet processing and secretion of proinsulin. Proinsulin processing was assessed by a $\left[{ }^{35} \mathrm{~S}\right]$ methionine-radiolabeling pulsechase experiment, where the pulse was at $16.7 \mathrm{mM}$ glucose to stimulate proinsulin biosynthesis and the chase at a basal 2.8 

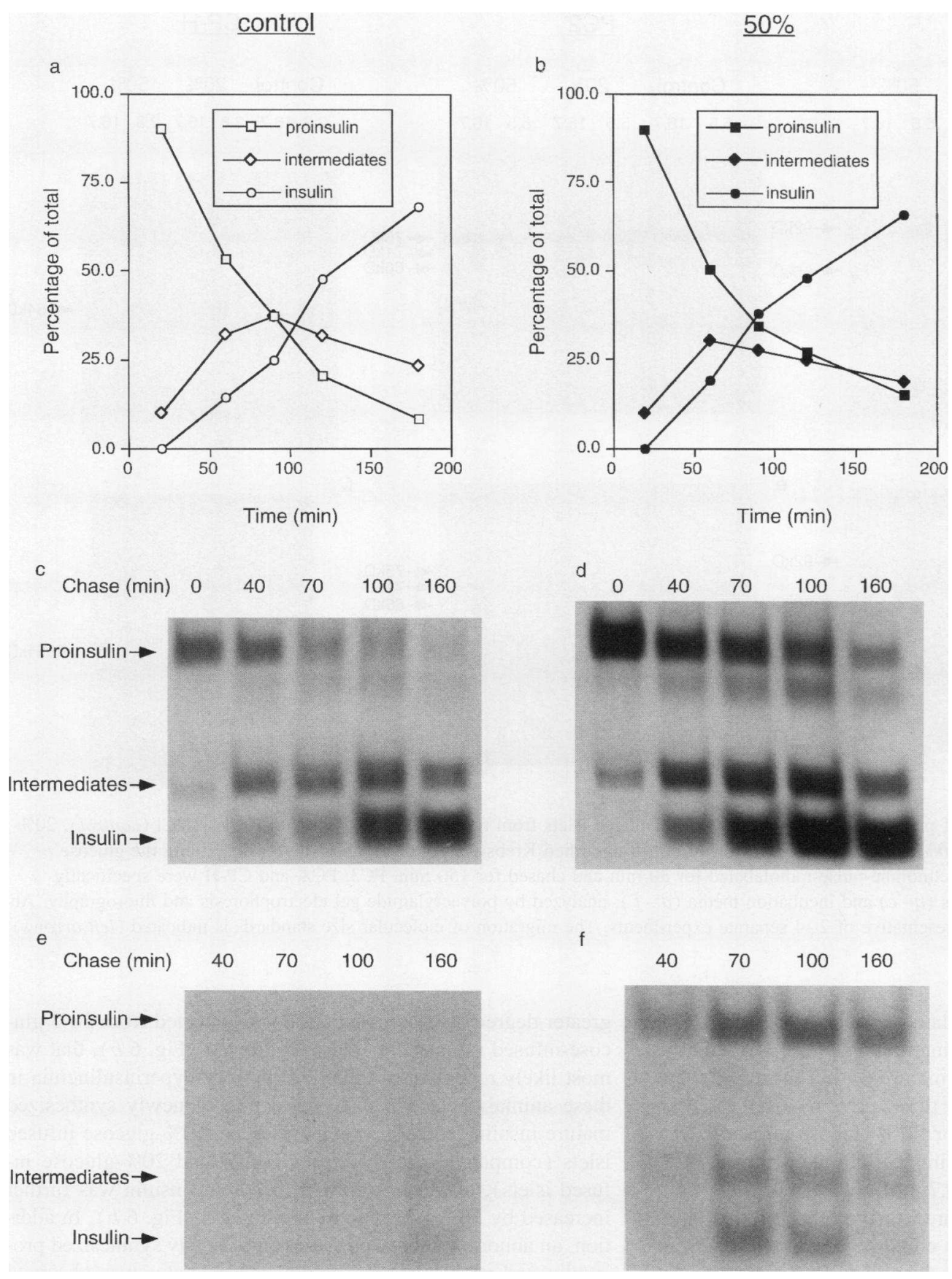

Figure 4. Proinsulin processing in hyperglycemic rat isolated islets. Isolated islets from rats infused for $48 \mathrm{~h}$ with $0.45 \% \mathrm{NaCl}$ (control) and $50 \%$-glucose $(50 \%)$ were preincubated for $30 \mathrm{~min}$ in modified Krebs-Ringer bicarbonate buffer containing $16.7 \mathrm{mM}$ glucose, then $\left[{ }^{35} \mathrm{~S}\right]$ methionine-pulseradiolabeled for $20 \mathrm{~min}$ at 16.7 $\mathrm{mM}$ glucose and chased at 2.8 $\mathrm{mM}$ glucose for the indicated times. Insulin-related proteins were specifically immunoprecipitated from islet lysates ( $c$ and $d$ ) and incubation media ( $e$ and $f$ ), analyzed by polyacrylamide gel electrophoresis and fluorography. The migration of insulin-related proteins is indicated. $a$ and $b$ show the densitometric scanner analysis of the islet fluorograms, expressed as percentage of total radioactivity into insulin-related proteins.

$\mathrm{mM}$ glucose to minimize (pro) insulin release (16). The rate of proinsulin processing, in terms of insulin production, was identical in the $50 \%$ glucose and the saline control islets through $180 \mathrm{~min}$ (Fig. 4, $a$ and $b$ ). However, by $180 \mathrm{~min}$ the amount of newly synthesized proinsulin was twice as high in hyperglycemic rats compared to controls (Fig. 4, $c$ and $d$ ), that was comparable to previous measurements of the islet content proinsulin to insulin ratio (24). Nevertheless, because of the increased biosynthesis of proinsulin in the $50 \%$ glucose-infused rats at $16.7 \mathrm{mM}$ glucose (Fig. 3; Fig. 4, $c$ vs. $d$ ), in absolute terms, the amount of newly synthesized proinsulin being converted to insulin by $180 \mathrm{~min}$ was almost twice that of the saline islets (Figs. 4, $c$ vs. $d$ ). Analysis of the incubation media was used to determine secretion of newly synthesized (pro) insulin
(Fig. $4 e$ ). As would be predicted (16), there was minimal secretion of (pro) insulin from the saline-infused control islets during the chase at basal $2.8 \mathrm{mM}$ glucose. In contrast, exaggerated secretion of proinsulin, conversion intermediates and insulin from $50 \%$ glucose-infused rat islets was observed throughout the chase period at $2.8 \mathrm{mM}$ glucose (Fig. $4 f$ ), with proinsulin being detectable at $60 \mathrm{~min}$ and the intermediates and insulin appearing somewhat later (Fig. $4 f$ ).

Islet processing and secretion of $P C 2, P C 3$, and $\mathrm{CP}-\mathrm{H}$. In further experiments, islets were $\left[{ }^{35} \mathrm{~S}\right]$ methionine pulse-radiolabeled for $30 \mathrm{~min}$ and chased for an additional $150 \mathrm{~min}$ at either basal glucose $(2.8 \mathrm{mM}$ and $5.5 \mathrm{mM}$ ) or stimulatory $16.7 \mathrm{mM}$ glucose (Fig. 5). During the chase, the $92-\mathrm{kD}$ precursor form of PC3 was processed normally to a mature $66-\mathrm{kD}$ form (29, 


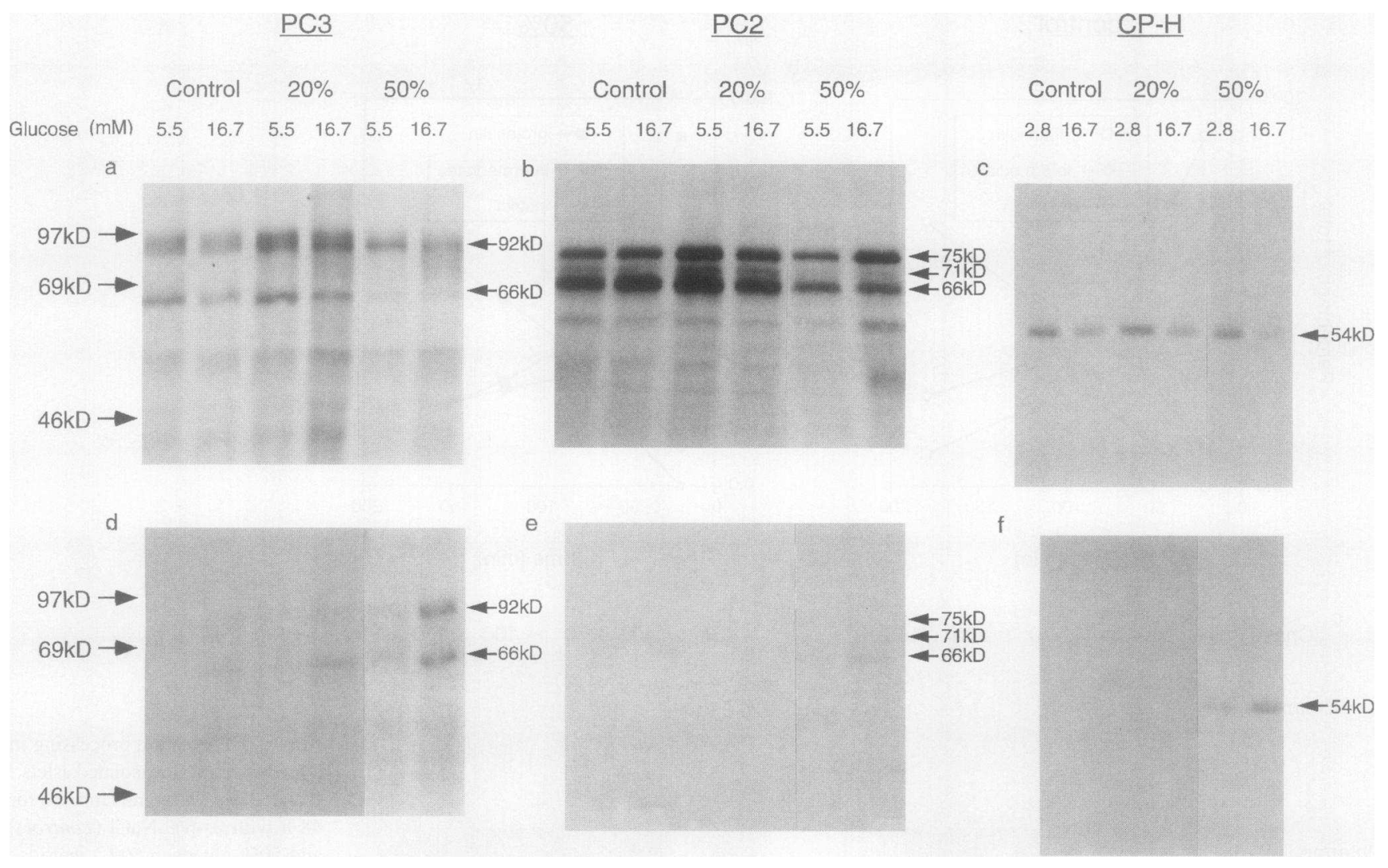

Figure 5. Biosynthesis and release of proinsulin-processing enzymes. Isolated islets from rats infused for $48 \mathrm{~h}$ with $0.45 \% \mathrm{NaCl}$ (control), 20\%glucose $(20 \%)$, and $50 \%$-glucose $(50 \%)$ were preincubated for $40 \mathrm{~min}$ in modified Krebs-Ringer bicarbonate buffer containing the glucose concentration indicated, then $\left[{ }^{35} \mathrm{~S}\right]$ methionine-pulse-radiolabeled for $30 \mathrm{~min}$ and chased for $150 \mathrm{~min}$. PC3, PC2, and CP-H were specifically immunoprecipitated from islet lysates $(a-c)$ and incubation media $(d-f)$, analyzed by polyacrylamide gel electrophoresis and fluorography. An example fluorogram is shown as representative of 2-4 separate experiments. The migration of molecular size standards is indicated (left arrows)

36), as was the $75-\mathrm{kD}$ glycosylated precursor of $\mathrm{PC} 2$ to its mature $66-\mathrm{kD}$ form via a $71-\mathrm{kD}$ intermediate $(29,37)$, and the $56-\mathrm{kD}$ precursor of $\mathrm{CP}-\mathrm{H}$ to its mature $54-\mathrm{kD}$ form (30). No deficiency in the processing of these proteins was noted in the $20 \%$ glucose-infused islets or $50 \%$ glucose-infused islets. However, there was an observed intracellular depletion of PC2, PC3, and CP-H (especially at $16.7 \mathrm{mM}$ glucose) in islets from $50 \%$-glucose infused rats compared to the other groups (Fig. $5, a-c)$. However, this depletion could be accounted for by an increased release of newly synthesized PC2, PC3, and CP-H at both basal glucose and stimulatory $16.7 \mathrm{mM}$ glucose concentrations in 50\%-glucose infused islets (Fig. 5, $d-f$ ). It has previously been shown that PC2 and CP-H are co-secreted with insulin from pancreatic islets $(35,37)$, and this study demonstrated that PC3 was also co-secreted in a parallel manner.

In the same experiment, $>92 \%$ of newly synthesized proinsulin was processed to insulin in the control and $20 \%$ glucoseinfused islets within the $150 \mathrm{~min}$ chase (Fig. $6 a$ ), whereas in the $50 \%$ glucose-infused islets the ratio of newly synthesized proinsulin to insulin suggested slightly less conversion $(\sim 85 \%$ proinsulin converted; Fig. $6 a$ ) comparable with previous observations (Fig. 4). The control and $20 \%$ glucose-infused islets secreted only newly synthesized mature insulin at 5.5 and 16.7 $\mathrm{mM}$ glucose as opposed to substantial amounts of the secreted peptides in the $50 \%$ glucose islets (even at $2.8 \mathrm{mM}$ glucose) being proinsulin and the intermediates (Figs. $4 f$ and $6 b$ ). A greater degree of insulin secretion was detected from $20 \%$ glucose-infused rat islets at $16.7 \mathrm{mM}$ glucose (Fig. $6 \mathrm{~b}$ ), that was most likely reflective of the compensatory hyperinsulinemia in these animals $(26,27)$. The basal rate of newly synthesized mature insulin secretion was increased in 50\%-glucose infused islets (compared with that from saline- and $20 \%$-glucose infused islets), however secretion of mature insulin was further increased by $16.7 \mathrm{mM}$ glucose stimulation (Fig. $6 \mathrm{~b}$ ). In addition, an abnormal increased secretion of newly synthesized proinsulin and proinsulin conversion intermediates was observed from $50 \%$ glucose-infused islets compared to saline- and $20 \%$ glucose-infused islets (Fig. $6 \mathrm{~b}$ ). In contrast to secretion of mature insulin from the same $50 \%$ glucose-infused islets, the release of proinsulin and proinsulin conversion intermediates was not stimulated by $16.7 \mathrm{mM}$ glucose (Fig. $6 b$ ).

\section{Discussion}

Hyperproinsulinemia in NIDDM is thought to reside at the level of $\beta$ cell dysfunction $(3,19,20)$. Such a dysfunction is likely a consequence of the increased secretory demand placed on the $\beta$ cell by chronic hyperglycemia and/or a defect in the $\beta$ cell's proinsulin processing machinery (3). In this study we examined the $\beta$ cell's handling of the proinsulin processing enzymes under hyperglycemic conditions in pancreatic islets isolated from 48h glucose-infused rats. In normoglycemic $20 \%$ glucose-infused 


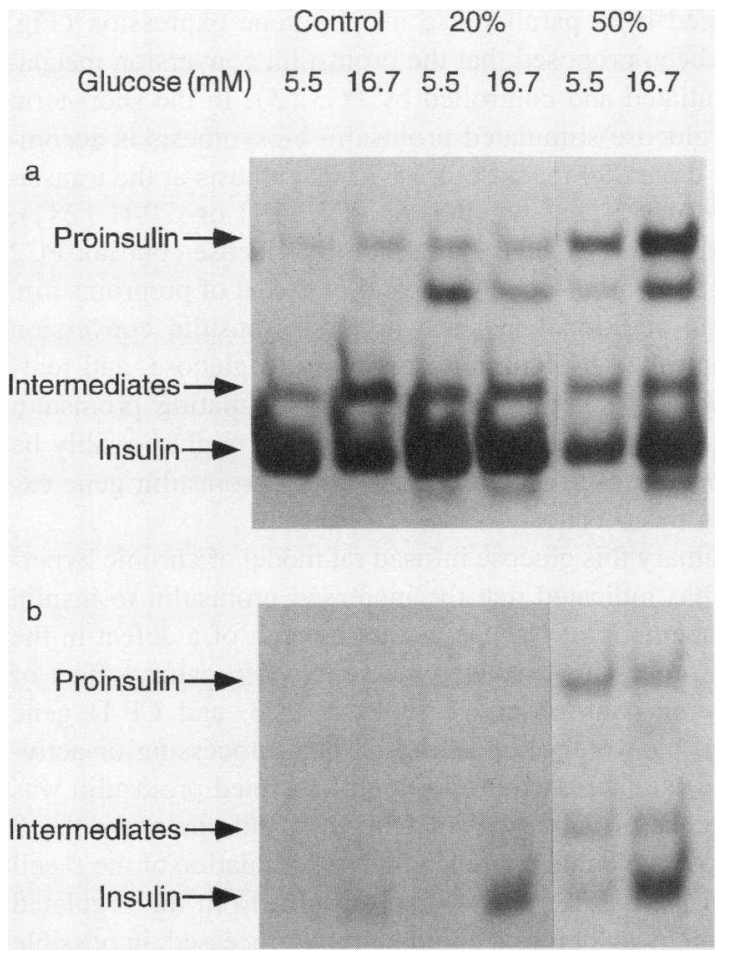

Figure 6. Biosynthesis and release of proinsulin. Isolated islets from rats infused for 48 hours with $0.45 \% \mathrm{NaCl}$ (control), $20 \%$-glucose $(20 \%)$, and $50 \%$-glucose $(50 \%)$ were preincubated for $40 \mathrm{~min}$ in modified Krebs-Ringer bicarbonate buffer containing 5.5 or $16.7 \mathrm{mM}$ glucose, then $\left[{ }^{35} \mathrm{~S}\right]$ methionine-pulse-radiolabeled for $30 \mathrm{~min}$ and chased for 150 $\mathrm{min}$. Insulin-related proteins were specifically immunoprecipitated from islet lysates $(a)$ and incubation media $(b)$, analyzed by polyacrylamide gel electrophoresis and fluorography. The migration of insulin-related proteins is indicated.

rat islets, there was no derogatory change in $\mathrm{PC} 2, \mathrm{PC} 3$, and $\mathrm{CP}-\mathrm{H}$ content compared with saline-infused control islets. In contrast, in the hyperglycemic $50 \%$ glucose-infused rats the islet content of PC2, PC3, and CP-H was depleted, similar to a reduction in $\beta$ cell insulin content previously observed (27). However, depletion of islet PC2, PC3, CP-H, or (pro)insulin content in hyperglycemic rats could not be correlated with any reduction in gene expression, biosynthesis or post translational processing of these proteins. Rather, decreased islet content of PC2, PC3, CP-H, and (pro)insulin was attributable to an increased rate of secretion of these proteins induced by hyperglycemia.

We have previously documented in normal rat islets that $>99 \%$ of (pro)insulin is secreted via a regulated secretory pathway $(16,38)$. Newly synthesized proinsulin has been observed to be released from the $\beta$ cell $45-60$ minutes after initial synthesis (16). This lag period reflects the fastest time required from synthesis on the endoplasmic reticulum to passage through the Golgi apparatus, packaging into secretory vesicles and transit to the plasma membrane for exocytosis $(1,16)$. From 60 min onwards newly synthesized (pro)insulin is secreted in a glucose-regulated manner indicating that it is derived from a secretory granule compartment and released via the $\beta$ cell's regulated secretory pathway $(16,38)$. Passage of newly synthesized proinsulin through the early stages of the $\beta$ cell's secretory pathway to an immature secretory granule compartment takes around 30 minutes (1). Thus, the minimum transit time for a newly formed secretory granule to be transported to the plasma membrane for exocytosis under glucose stimulatory conditions can be estimated to be $\geq 30 \mathrm{~min}$ (16). However, the immature secretory granule compartment is the major site of proinsulin in the $\beta$ cell $(1,2,39)$, and it has been established that $3 \mathrm{~h}$ after proinsulin synthesis is the time period necessary for $90 \%$ of newly synthesized proinsulin to be converted to insulin within the normal $\beta$ cell $(1,16,17,40)$. It has also been shown that there is preferential secretion of newly synthesized (pro)insulin, so that up to $50 \%$ of the initial proinsulin synthesized can be released within the same $3 \mathrm{~h}$ period at maximal glucose stimulatory conditions $(16,41)$. It follows therefore, that under maximal glucose stimulatory conditions newly synthesized (pro)insulin released between 60-120 min (post proinsulin synthesis) would be reflective of the content of immature secretory granules in which proinsulin conversion is only partially completed, and thus a higher proportion of newly synthesized proinsulin can be released (16). In normal islets glucose stimulated insulin release is mostly reflective of exocytosis from the mature insulin secretory granule storage pool, and the proportion of newly synthesized (pro) insulin contributed from immature secretory granules is relatively minor $(41,16)$. However, this may not be the situation in islets exposed to severe chronic hyperglycemia, such as the $50 \%$ glucose-infused islets described in this study. The increased secretory demand placed on the $\beta$ cell by the hyperglycemia results in a $75 \%$ depletion in $\beta$ cell secretory granule content $(26,27)$. Furthermore, the persistent elevation in blood glucose in the $50 \%$ glucose-infused rats also induced increased proinsulin biosynthesis (Figs. 3, 4, and 6), and presumably secretory granule biogenesis (28). Thus, in $50 \%$ glucose-infused islets there is likely to be a much higher proportion of immature secretory granules present, which are preferentially and rapidly transported to the plasma membrane for exocytosis before the newly synthesized proinsulin has been fully converted to insulin. As a result, there is an increased proportion of proinsulin (and conversion intermediates) released from the $\beta$ cell's regulated secretory pathway under hyperglycemic conditions, the consequences of which is a raised proinsulin to insulin ratio in the circulation.

This study indicated there was also a proportion of abnormal (pro)insulin secretion arising from chronic exposure to severe hyperglycemia. Several lines of evidence indicated an increased proportion of (pro)insulin was released in an unregulated manner from the $50 \%$ glucose-infused islets compared to salineinfused control islets. First, a rapid secretion of newly synthesized proinsulin from $50 \%$ glucose-infused islets was observed under non-stimulated conditions $(2.8 \mathrm{mM}$ glucose in the chase medium) 20-60 min after initial proinsulin synthesis, followed by an unregulated release of proinsulin, conversion intermediates and insulin in the subsequent 60-120-min period (Fig. 4 $f$ ). Negligible release of (pro)insulin was observed in the saline-infused control islets incubated at a basal $2.8 \mathrm{mM}$ glucose (Fig. $4 e$ ). Second, under normal conditions, secretion of PC2, PC3, and CP-H was only observed under glucose stimulation implying that these proteins were co-released with insulin via the $\beta$ cell's regulated secretory pathway $(35,37,38)$. However, in $50 \%$ glucose-infused islets the basal rate (at 2.8 or $5.5 \mathrm{mM}$ glucose) of PC2, PC3, and $\mathrm{CP}-\mathrm{H}$ secretion was increased in parallel to that of (pro)insulin (Figs. 5 and 6) compared with that from $20 \%$ - and saline-infused rat islets, implying a increased proportion of unregulated secretion in islets exposed to 
hyperglycemia. Third, a most intriguing observation was that from the very same $50 \%$ glucose-infused islets release of newly synthesized proinsulin and proinsulin conversion intermediates was not regulated by glucose whereas, in contrast, secretion of newly synthesized mature insulin was clearly stimulated by glucose (Fig. $6 \mathrm{~b}$ ). This raises the possibility that in the $50 \%$ glucose-infused islets a proportion of newly synthesized proinsulin (and proinsulin conversion intermediates) were independently released from a different, nonregulatable, intracellular pool compared to the majority of newly synthesized mature insulin which was secreted in a regulated manner. It should be noted that in saline-infused control and $20 \%$ glucose-infused islets there was negligible release of proinsulin or proinsulin conversion intermediates (Fig. $6 b$ ). The abnormal (pro) insulin secretion from $50 \%$ glucose-infused islets may be symptomatic of the severe chronic hyperglycemia increasing the proportion of immature secretory granules and their transit time to the plasma membrane for exocytosis. However, other possible explanations should be considered such as functional $\beta$ cell heterogeneity within hyperglycemic islets (42), or abnormal and/or loss of glucose sensing by islets exposed to chronic hyperglycemia $(3,18,26,27)$. In addition, a partial factor could be an increased contribution of (pro)insulin secreted in an unregulated manner, perhaps via a constitutive-like pathway $(38,43)$. In normal rat islets a small amount of rapidly released newly synthesized proinsulin $(<1 \%$ of the total proinsulin synthesized secreted from islets between 30 and $60 \mathrm{~min}$ ) is not subjected to regulation by glucose, and may therefore be representative of a minor degree of proinsulin released via a constitutive pathway $(16,38,43)$. However, in islets exposed to severe chronic hyperglycemia (where there is larger quantities of newly synthesized proinsulin traversing the secretory pathway due to corresponding increased proinsulin biosynthesis caused by the increased secretory demand placed on the $\beta$ cell), the contribution of (pro)insulin missorted for secretion via an unregulated constitutive pathway may be increased. Nevertheless, it is clear that further studies are required to more thoroughly characterize this abnormal (pro)insulin secretion from islets exposed to severe chronic hyperglycemia, to better implicate the aforementioned hypotheses.

Aside from the derogatory effect of chronic hyperglycemia on the $\beta$ cell's secretory pathway, there were some other interesting aspects of the results concerning glucose regulation of PC3 and proinsulin biosynthesis that warrant discussion. In islets from $20 \%$ and $50 \%$ glucose-infused rats it was found that the basal rate of proinsulin and PC3 biosynthesis was raised (Fig. 3). This abnormality may well be associated with the loss of glucose-sensitivity for regulated insulin secretion in the $50 \%$ glucose-infused rat model $(18,26,27)$, supporting the idea that there is likely to be certain shared elements in the glucose sensing stimulus-coupling mechanisms for insulin secretion and biosynthesis (44). Alternatively, the "off-rate" for glucosestimulated proinsulin biosynthesis is relatively slow (45), and the increased basal rate of proinsulin/PC3 biosynthesis in hyperglycemic islets could result from a slowed shut down process as a "memory" of the prior hyperglycemia. Another explanation might be that the amount of preproinsulin/PC3 mRNA available for translation increased in $50 \%$ glucose-infused islets (Fig. 2) which, in turn, was reflected as enhanced basal proinsulin/PC3 biosynthesis. Under longer term situations, such as prolonged hyperglycemia, an increase in preproinsulin mRNA has been previously observed (46), that this study indicated is accompanied by a parallel rise in PC3 gene expression (Fig. 2 ). It has been proposed that the proinsulin conversion mechanism is initiated and controlled by PC3 (3). In the short-term $(<2 \mathrm{~h})$, glucose-stimulated proinsulin biosynthesis is accompanied by a parallel increase in PC3 biosynthesis at the translational level (29) (but not that of PC2 [29] or CP-H [28]). Thus, increased PC3 gene expression by glucose (but not PC2 or $\mathrm{CP}-\mathrm{H}$ gene transcription ), in parallel to that of preproinsulin, provides an additional means whereby proinsulin conversion can be controlled by long term exposure to glucose, and reaffirms PC3 as the key endopeptidase in regulating proinsulin processing (3). Similar transcription factors might possibly be involved in glucose-regulated PC3 and preproinsulin gene expression in the $\beta$ cell.

In summary this glucose infused rat model of chronic hyperglycemia has indicated that the increased proinsulin to insulin ratio characteristic of NIDDM is not a result of a defect in the proinsulin processing enzymes per se. No derogatory effect of hyperglycemia was observed on $\mathrm{PC} 2, \mathrm{PC} 3$, and $\mathrm{CP}-\mathrm{H}$ gene expression, biosynthesis, posttranslational processing or activity. Rather, the increased proportion of secreted proinsulin was a consequence of increased secretory demand placed on the $\beta$ cell by hyperglycemia. Chronic glucose stimulation of the $\beta$ cell resulted in premature release of proinsulin from the regulated secretory pathway before it could be fully processed, in possible combination with a defective increase in unregulated (pro)insulin release. Thus a functional, rather than microanatomical, defect may account for hyperproinsulinemia in this model of chronic severe hyperglycemia. However, it should be noted that the glucose-infused rat is only one experimental model of NIDDM that is characterized by marked chronic hyperglycemia. Thus, questions will persist as to relevance of these findings to less hyperinsulinemic states with hyperglycemia, more common to NIDDM. Since NIDDM likely encompasses a family of disorders, it will be important to pursue similar studies in other animal models of NIDDM. Thus, hyperproinsulinemia as a result from a direct dysfunction in proinsulin processing enzyme activity in the $\beta$ cell rather than a secretory defect (3) should not yet be ruled out in other experimental animal models or various forms of human NIDDM.

\section{Acknowledgments}

We thank Dr. Iris Lindberg (LSU Medical Center, New Orleans, LA) for PC3 antiserum, Dr. Lloyd Fricker (Albert Einstein College of Medicine, Bronx, NY) for carboxypeptidase-H antiserum and cDNA, Dr. Al Rehemtulla (The Genetics Institute, Cambridge, MA) for PC2 and PC3 cDNA, and Dr. Lydia Villa-Komaroff for rat preproinsulin-II cDNA.

This work was supported in part by the Juvenile Diabetes Foundation International and National Institutes of Health Grants DK-36836 and DK-38543. C. J. Rhodes is the recipient of a Juvenile Diabetes Foundation International Career Development Award.

\section{References}

1. Orci, L. 1985. The insulin factory: a tour of the plant surroundings and a visit to the assembly line. Diabetologia. 28:528-546.

2. Orci, L., M. Ravazzola, M.-J. Storch, R. G. W. Anderson, J.-D. Vassalli, and A. Perrelet. 1987. Proteolytic maturation of insulin is a post-Golgi event which occurs in acidyfying clathrin-coated secretory vesicles. Cell. 49:865-868.

3. Rhodes, C. J., and C. Alarcón. 1994. What $\beta$-cell defect could lead to hyperproinsulinemia in NIDDM: some clues from recent advances made in understanding the proinsulin conversion mechanism. Diabetes. 43:511-517.

4. Davidson, H. W., C. J. Rhodes, and J. C. Hutton. 1988. Intraorgenellar Ca 
and $\mathrm{pH}$ control proinsulin cleavage in the pancreatic $\beta$-cell via two site-specific endopeptidases. Nature (Lond.). 333:93-96.

5. Smeekens, S. P., and D. F. Steiner. 1990. Identification of a human insulinoma cDNA encoding a novel mammalian protein structurally related to the yeast dibasic processing KEX2. J. Biol. Chem. 265:2997-3000.

6. Smeekens, S. P., A. S. Avruch, J. LaMendola, S. J. Chan, and D. F. Steiner 1991. Identification of a cDNA encoding a second putative prohormone convertase related to PC2 in AtT20 cells and islets of Langerhans. Proc. Natl. Acad. Sci. USA. 88:340-344.

7. Davidson, H. W., and J. C. Hutton. 1987. The insulin secretory granule carboxypeptidase-H. Purification and demonstration of involvement in proinsulin processing. Biochem. J. 245:575-582.

8. Seidah, N. G., M. Marcinkiewicz, S. Benjannet, L. Gaspar, G. Beaubien, M. G. Mattei, C. Lazure, M. Mbikay, and M. Chétien. 1991. Cloning and primary sequence of a mouse candidate prohormone convertase PC1 homologous to PC2, Furin, and Kex2: Distinct chromosomal localisation and messenger RNA distribution in brain and pituitary compared to PC2. Mol. Endocrinol. 5:111-122.

9. Steiner, D. F., S. P. Smeekens, S. Ohagi, and S. J. Chan. 1992. The new enzymology of precursor processing endopeptidases. J. Biol. Chem. 267:2343523438.

10. Hutton, J. C. 1991. Subtilisin-like proteinases involved in the activation of proproteins of the secretory pathway of eukaryotic cells. Curr. Opin. Cell Biol. 2:1131-1142.

11. Rhodes, C. J., B. Lincoln, and S. E. Shoelson. 1992. Preferential cleavage of des 31,32 proinsulin over intact proinsulin by the insulin secretory granule typeII endopeptidase: Implications for a favoured route for prohormone processing. $J$. Biol. Chem. 267:22719-22727.

12. Bailyes, E. M., D. L. Bennett, and J. C. Hutton. 1991. Proprotein-processing endopeptidases of the insulin secretory granule. Enzyme. 45:301-313.

13. Bailyes, E. M., K. I. J. Shennan, A. J. Seal, S. P. Smeekens, D. F. Steiner, J. C. Hutton, and K. Docherty. 1992. A member of the eukaryotic subtilisin family (PC3) has the enzymic properties of the type-I proinsulin-converting endopeptidase. Biochem. J. 285:391-394.

14. Smeekens, S. P., A. G. Montag, G. Thomas, C. Albiges-Rizo, R. Carroll, M. Benig, L. A. Phillips, S. Martin, S. Ohagi, P. Gardner, H. H. Swift, and D. F. Steiner. 1992. Proinsulin processing by the subtilisin-related proprotein covertases furin, PC2 and PC3. Proc. Natl. Acad. Sci. USA. 89:8822-8826.

15. Bennett, D. L., E. M. Bailyes, E. Nielson, P. C. Guest, N. G. Rutherford S. D. Arden, and J. C. Hutton. 1992. Identification of the type-II proinsulin processing endopeptidase as PC2, a member of the eukaryotic subtilisin family. J. Biol. Chem. 267:15229-156.

16. Rhodes, C. J., and P. A. Halban. 1987. Newly-synthesized proinsulin/ insulin and stored insulin are released form pancreatic B-cells via a regulated, rather than a constitutive pathway. J. Cell Biol. 105:145-153.

17. Sizonenko, S., J.-C. Irminger, L. Buhler, S. Deng, P. Morel, and P. Halban. 1993. Kinetics of proinsulin conversion in human islets. Diabetes. 42:933-936.

18. Leahy, J. L. 1990. Natural History of B-cell Dysfunction in NIDDM Diabetes Care. 13:992-1010.

19. Porte, D., and S. E. Kahn. 1989. Hyperproinsulinemia and amyloid in NIDDM: Clues to etiology of islet $\beta$-cell dysfunction. Diabetes. 38:1333-1336

20. Leahy, J. L., S. Bonner-Weir, and G. C. Weir. 1992. $\beta$-cell dysfunction by chronic hyperglycemia: current ideas on mechanism of glucose-induced insulin secretion. Diabetes Care. 15:442-454.

21. Temple, R. C., C. A. Carrington, S. D. Luzio, D. R. Owens, A. E. Schneider, W. J. Sobey and C. N. Hales. 1989. Insulin deficiency in non-insulindependent diabetes. Lancet. 293-295.

22. Polonsky, K. S., and A. H. Rubenstein. 1990. The kinetics and metabolism of insulin, proinsulin, and C-peptide. In Endocrinology. L. G. DeGroot, editor W. B. Saunders Co., Harcourt Brace Jovanovich Inc., Philadelphia. 1304-1317.

23. Leahy, J. L., P. A. Halban, and G. C. Weir. 1991. Relative hypersecretion of proinsulin in rat model of NIDDM. Diabetes. 40:985-989.

24. Leahy, J. L. 1993. Increased proinsulin/insulin ratio in pancreas extracts of hyperglycemic rats. Diabetes. 42:22-27.

25. Tillil, H., B. H. Frank, A. H. Pekar, C. Broelsch, A. H. Rubenstein, and
K. S. Polonsky. 1990. Hypoglycemic potency and metabolic clearance rate of intravenously administered human proinsulin and metabolites. Endocrinology. 127:2418-2422.

26. Leahy, J. L., and G. C. Weir. 1988. Evolution of abnormal insulin secretory responses during 48-h in vivo hyperglycemia. Diabetes. 37:217-222.

27. Leahy, J. L., H. E. Cooper, D. A. Deal, and G. C. Weir. 1986. Chronic hyperglycemia is associated with impaired glucose on insulin secretion: A study in normal rats using chronic in vivo glucose infusions. J. Clin. Invest. 77:908915 .

28. Guest, P. G., C. J. Rhodes, and J. C. Hutton. 1989. Regulation of the biosynthesis of insulin secretory granule proteins: co-ordinate translational control is exerted on some but not all granule matrix constituents. Biochem. J. 257:431437.

29. Alarcón, C., B. Lincoln, and C. J. Rhodes. 1993. The biosynthesis of the subtilisin-related proprotein covertase PC3, but not that of the PC2 convertase, is regulated by glucose in parallel to proinsulin biosynthesis in rat pancreatic islets. J. Biol. Chem. 268:4276-4280.

30. Fricker, L. D., and L. Devi. 1993. Posttranslational processing of carboxypeptidase E, a neuropeptide-processing enzyme, in AtT-20 cells and bovine pituitary secretory granules. J. Neurochem. 61:1404-1415.

31. Laemmli, U. K. 1970. Cleavage of structural proteins during the assembly of the head of bacteriophage T4. Nature (Lond.). 227:680-685.

32. Fricker, L. D., J. Adelman, J. Douglas, J. Thompson, R. Pogge von Strandmann, and J. C. Hutton. 1989. Isolation and sequnce analysis of rat carboxypeptidase E cDNA. Mol. Endocrinol. 3:666-673.

33. Gross, D. J., L. Villa-Komaroff, C. R. Kahn, G. W. Weir, and P. A. Halban. 1989. Deletion of a highly conserved tetrapeptide sequence of the proinsulin connecting peptide (C-peptide) inhibits proinsulin to insulin conversion by transfected pituitary corticotroph (AtT20) cells. J. Biol. Chem. 264:2148621490

34. Neerman-Arbez, M., V. Cirulli, and P. A. Halban. 1994. Levels of the conversion endoproteases $\mathrm{PCl}$ (PC3) and PC2 distinguish between insulin-producing pancreatic beta cells and non-beta cells. Biochem. J. 300:57-61.

35. Guest, P. G., D. Pipeleers, J. Rossier, C. J. Rhodes, and J. C. Hutton. 1989. Co-secretion of carboxypeptidase- $\mathrm{H}$ and insulin from isolated rat islets of Langerhans. Biochem. J. 264:503-508.

36. Vindrola, O., and I. Lindberg. 1992. Biosynthesis of the prohormone convertase mPC1 in AtT-20 cells. Mol. Endocrinol. 6:1088-1094.

37. Guest, P. C., S. D. Arden, D. L. Bennett, A. Clark, N. G. Rutherford, and J. C. Hutton. 1992. The post-translational processing and intracellular sorting of PC2 in the islets of Langerhans. J. Biol. Chem. 267:22401-22406.

38. Burgess, T. L., and R. B. Kelly. 1987. Constitutive and regulated secretion of proteins. Annu. Rev. Cell Biol. 3:243-293.

39. Rhodes, C. J., C. A. Lucas, R. L. Mutkoski, L. Orci, and P. A. Halban. 1987. Stimulation by ATP of proinsulin to insulin conversion in isolated rat pancreatic islet secretory granules: association with ATP-dependent proton pump. J. Biol. Chem. 262:10712-10717.

40. Steiner, D. F., G. I. Bell, and H. S. Tager. 1990. Chemistry and biosynthesis of pancreatic protein hormones. In Endocrinology. L. G. DeGroot, editor. W. B. Saunders Co., Harcourt Brace Jovanovich Inc., Philadelphia. 1263-1289.

41. Halban, P. A. 1982. Differential rates of release of newly synthesised and of stored insulin from pancreatic islets. Endocrinol. 110:1183-1188.

42. Pipeleers, D. G. 1992 . Heterogeneity in pancreatic $\beta$-cell population. Diabetes. 41:777-781.

43. Kuliawat, R., and P. Arvan. 1992. Protein targetting via the "constitutivelike" pathway in isolated pancreatic islets: passive sorting in the immature granule. J. Cell Biol. 118:521-529.

44. Ashcroft, S. J. H. 1980. Glucoreceptor mechanisms and the control of insulin release and biosynthesis. Diabetologia. 18:5-15.

45. Kaelin, D., A. E. Renold, and G. W. G. Sharp. 1978. Glucose-stimulated proinsulin biosynthesis. Rates of turn off after ceasation of the stimulus. Diabetologia. 14:329-335.

46. Giddings, S. J., J. Chirgwin and M. A. Permutt. 1982. Effects of glucose on proinsulin mRNA in rats in vivo. Diabetes. 31:624-629. 